\title{
DESIGN AND ROTOR GEOMETRY ANALYSIS OF PERMANENT MAGNET-ASSISTED SYNCHRONOUS RELUCTANCE MACHINES USING FERRITE MAGNET
}

\author{
Zhiwei Zhang — Libing Zhou *
}

\begin{abstract}
Various electric machines can be the candidate for electric vehicles applications, including induction machines, permanent magnet synchronous machines, switched reluctance machines, etc. Another class of machine, which has been relatively ignored, is synchronous reluctance machines. In order to enhance and increase torque density of pure synchronous reluctance machines, the low cost permanent magnet can be inserted into rotor lamination to contribute torque production, which is so-called permanent magnet- assisted synchronous reluctance machines. This paper presents the design and rotor geometry analysis of low cost ferrite permanent magnet-assisted synchronous reluctance machines with transversally-laminated rotor. The advanced finite element method will be employed to calculate $d$-axis and $q$-axis inductance variation with rotor geometric parameters. The electromagnetic performance of optimized permanent magnet-assisted synchronous reluctance machines will be evaluated as well.
\end{abstract}

K e y w ords: permanent magnet-assisted, synchronous reluctance machines, ferrite, rotor geometry, inductance

\section{INTRODUCTION}

Electrical vehicles or hybrid electrical vehicle has received much more attentions due to energy crisis and environment concerns [1-3]. The performance requirements for electrical vehicle $(\mathrm{EV})$ traction applications include as follows: high torque and power density; high efficiency over wide torque and speed range; wide constant power speed range; high torque for starting, acceleration, and hill climbing; intermittent overload capability, extending to nearly twice rated torque for short durations; low torque ripple, vibration and noise; low volume, cost and weight [3].

Permanent magnet synchronous machines are popular in electric vehicle traction systems due to its high torque density, high efficiency, etc [4]. However, in high speed operation range, the dominant component of stator current are demagnetization current to weaken the flux produced by stronger rare earth permanent magnet, particularly in deep flux weakening operation. Other significant challenging issues are high costs, limited resources, and unstable products supply of rare earth permanent magnet.

The synchronous reluctance machine, which differs from the switched reluctance machine, has been relatively ignored. The stator of synchronous reluctance machines is constructed from a cylindrical structure and equipped with conventional distributed winding. Hence, the several disadvantages of switched reluctance machines, such as high torque pulsation, vibration and noise, can be improved in sinusoidal-excited synchronous reluctance machines [5]. Unfortunately, the torque density and power factor of pure synchronous reluctance machines are relatively poor. The axially-laminated rotor has been proposed to enlarge saliency ratio [6]. However, the disadvantages of axially-laminated rotor include higher eddy current rotor loss because of harmonic air-gap field and relatively complicated mechanical construction. For transversally-laminated rotor, single or multi-layer flux barriers are necessary to decrease $d$-axis reluctance and inductance. However, the saliency ratio cannot exceed theoretical limitation because of magnetic saturation and mechanical stress consideration. On the other hand, in order to enhance and increase torque density of pure synchronous reluctance machines, the permanent magnet can be inserted into rotor lamination to contribute torque production, which is so-called permanent magnet-assisted synchronous reluctance machines (PMA-SynRM). It will be a good candidate for next generation electric vehicle traction applications [7-9].

The $d$-axis and $q$-axis inductance play a key role in electromagnetic performance of permanent magnet-assisted synchronous reluctance machines and synchronous reluctance machines. The larger difference and ratio between $d$-axis and $q$-axis inductance are desirable in permanent magnet-assisted synchronous reluctance machines for torque capability and performance improvement. Furthermore, the significant design consideration of PMA-SynRM, which differs from conventional Interior permanent magnet machines, is to enhance reluctance torque and reduce the volume of permanent magnet by optimal electromagnetic design.

* State Key Laboratory of Advanced Electromagnetic Engineering and Technology, School of Electrical and Electronic Engineering, Huazhong University of Science and Technology, Wuhan, China, zwzhangieee@gmail.com 


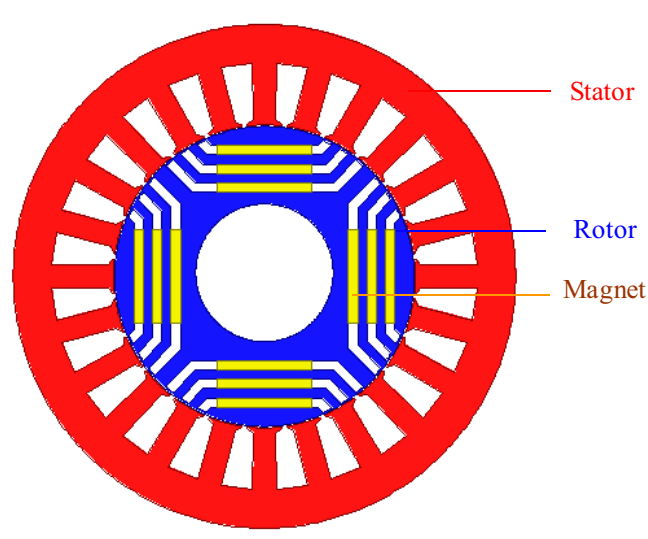

Fig. 1. Cross section of proposed permanent magnet-assisted synchronous reluctance machines

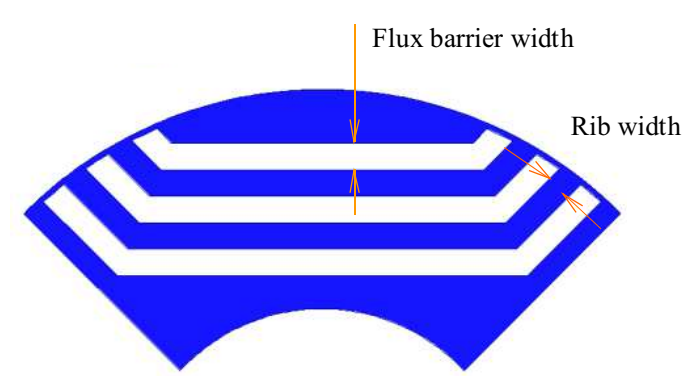

Fig. 2. Rotor lamination of proposed permanent magnet-assisted synchronous reluctance machines

This paper presents the design and rotor geometry analysis of low cost ferrite permanent magnet-assisted synchronous reluctance machines with transversally-laminated rotor. Electromagnetic torque production principle and equation will be illustrated firstly. The advanced finite element method will be used to calculate $d$-axis and $q$-axis inductance variation with rotor geometry. The electromagnetic performance of optimized PM-assisted synchronous reluctance machines will be evaluated as well.

\section{TORQUE PRODUCTION AND EQUATIONS}

Figure 1 shows cross section of proposed permanent magnet- assisted synchronous reluctance machines. The low cost ferrite permanent magnet has been used in this machine, instead of rare earth magnet materials in conventional interior permanent magnet (IPM) synchronous machines. The definition of d-axis and q-axis position was similar to conventional IPM synchronous machines.

The instantaneous electromagnetic torque in sinusoidal excited permanent magnet-assisted synchronous reluctance machines can be expressed by

$$
\begin{array}{r}
T_{e}=\frac{3}{2} p\left[\left(L_{d}-L_{q}\right) i_{q} i_{d}+\lambda_{P M} i_{q}\right]=\frac{3}{2} p\left[\frac{1}{2}\left(L_{d}-L_{q}\right) i_{s}^{2} \sin 2 \gamma\right. \\
\left.+\lambda_{P M} i_{s} \cos \gamma\right]=T_{r e l}+T_{P M}
\end{array}
$$

where $p$ is number of pole pairs, $L_{d}$ is $d$-axis synchronous inductance, $L_{q}$ is $q$-axis synchronous inductance, $i_{d}, i_{q}$ are $d$-axis and $q$-axis current components, $\lambda_{P M}$ is flux linkage due to permanent magnet. It can be seen that the electromagnetic torque can be separated into two terms. The first term is reluctance torque, which determined by $i_{d}, i_{q}$ and inductance difference of $d$-axis and $q$-axis inductance. The second term is magnet torque, which is proportional to the product of $i_{q}$ and $\lambda_{P M}$ [4]. $T_{r e l}$ is the reluctance torque component, $T_{P M}$ is the magnet torque component. $\gamma$ is current vector angle with $q$-axis.

For pure synchronous reluctance machine, which has no magnet torque contribution, the electromagnetic torque can be simplified an expressed by

$$
T_{e}=\frac{3}{2} p\left[\left(L_{d}-L_{q}\right) i_{q} i_{d}\right]=\frac{3}{2} p\left[\frac{1}{2}\left(L_{d}-L_{q}\right) i_{s}^{2} \sin 2 \gamma\right] .
$$

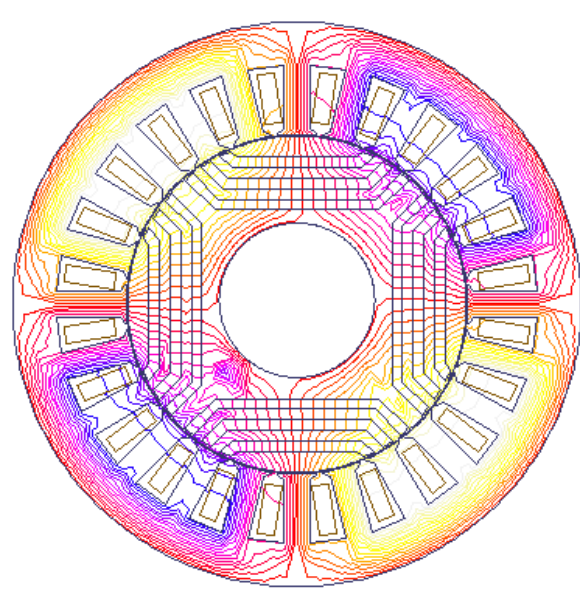

(a)

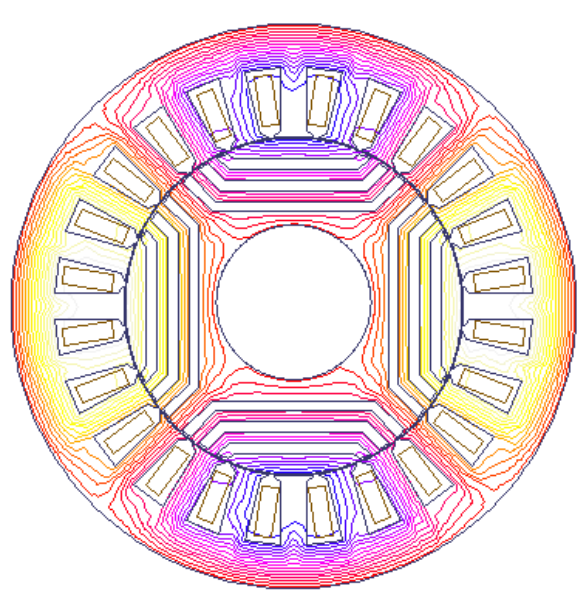

(b)

Fig. 3. FE-predicted 2D flux line plot of proposed permanent magnet-assisted synchronous reluctance machines: (a) $-d$-axis current excitation, (b) $-q$-axis current excitation 

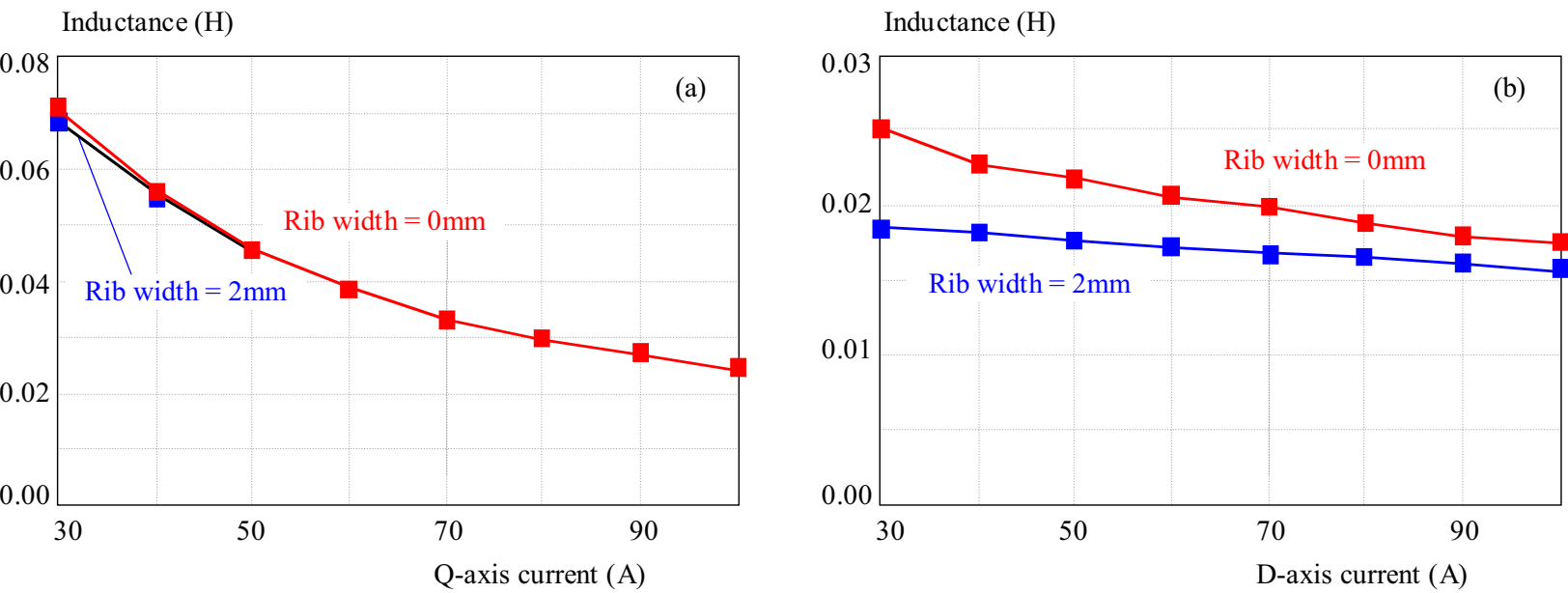

Fig. 4. FE-predicted inductance variation with rib of proposed PMA-SynRM: (a) - $q$-axis inductance, (b) - $d$-axis inductance
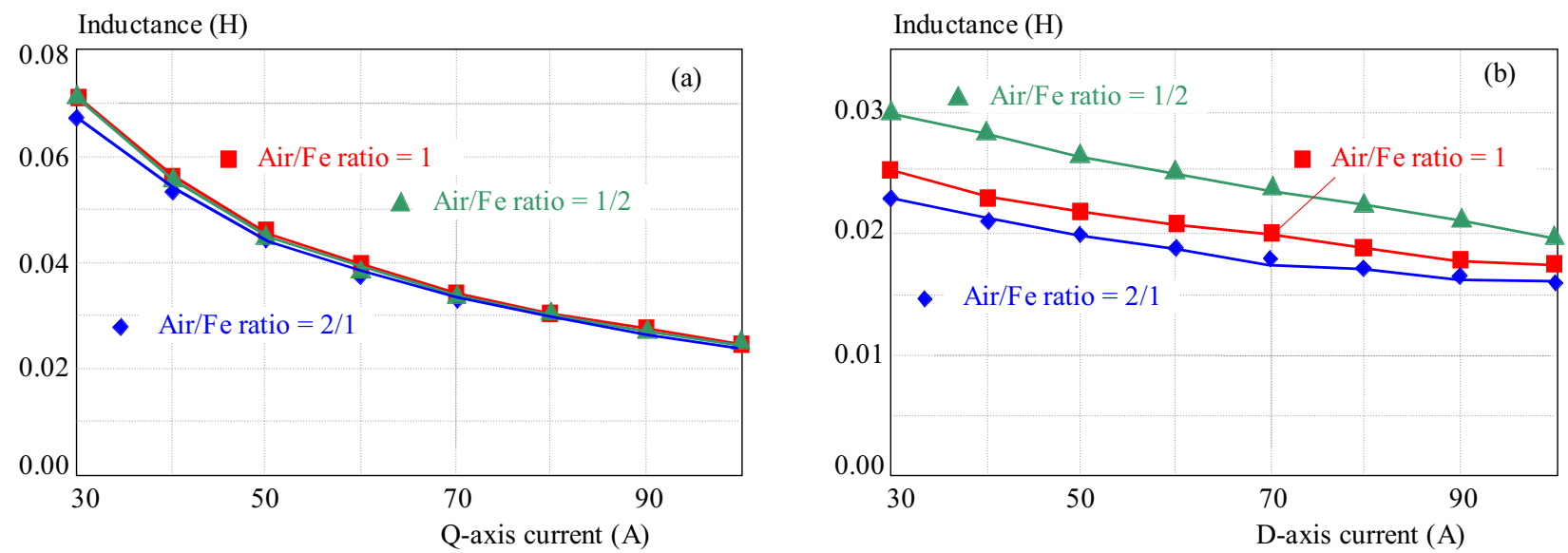

Fig. 5. FE-predicted inductance variation with air/fe ratio of proposed PMA-SynRM: (a) - $q$-axis inductance, (b) - $d$-axis inductance

Power factor is another significant performance parameter in pure synchronous reluctance machines and the maximum value of power factor can be expressed by $[6,10]$

$$
\cos \phi=\frac{k_{s r}-1}{k_{s r}+1}
$$

where $k_{s r}$ is saliency ratio, which can be defined as $k_{s r}=$ $L_{q} / L_{d}$.

It should be pointed out that from the torque and power factor equation, the $d$-axis and $q$-axis inductance play an important role in performance of both pure synchronous reluctance machines and permanent magnetassisted synchronous reluctance machines. Furthermore, one of the most significant design criteria in synchronous reluctance and permanent magnet-assisted synchronous reluctance machine is to increase inductance difference and ratio by rotor design optimization. Therefore, the influence of rotor geometric parameters on synchronous inductance variation should be investigated for torque density and performance improvement.

\section{ROTOR GEOMETRY ANALYSIS}

The finite element method will be employed to calculate $d$-axis and $q$-axis inductance of permanent magnetassisted synchronous reluctance machines in this section. Impact of significant rotor geometric parameters on inductance variation will be investigated as well. Figure 2 shows rotor lamination of proposed PMA-SynRM. Figure 3 shows the flux line distribution when current vector oriented with $d$-axis and $q$-axis. In order to observe the armature reaction field clearly, the permanent magnet in rotor has been removed. Due to reluctance difference, the $q$-axis inductance will be larger than $d$-axis inductance, which is similar with conventional interior permanent magnet synchronous machines.

Figure 4 shows $d$-axis and $q$-axis variation with rib width. As can be seen that $d$-axis inductance decrease when rib width changed from $2 \mathrm{~mm}$ to $0 \mathrm{~mm}$. Hence, inductance difference, saliency ratio and associated average reluctance torque will increase. However, form construction and mechanical stress point of view, rib width has to meet the requirement of mechanical limitation, particularly for high speed operation. In order to investigate the 


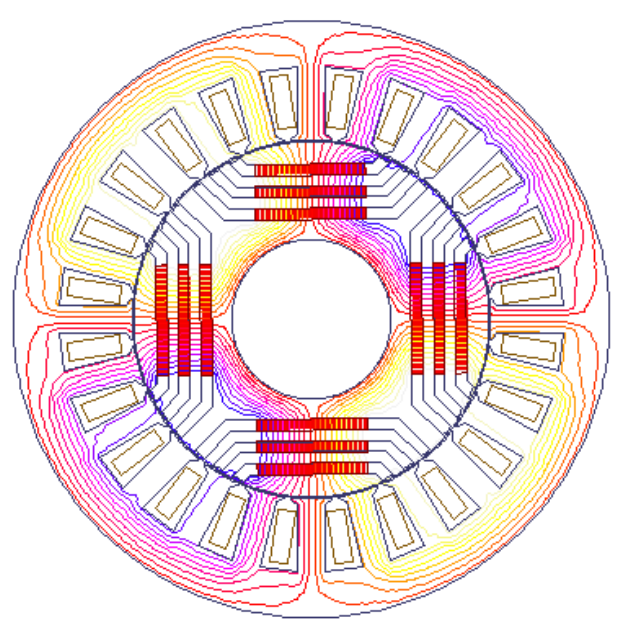

Fig. 6. FE-predicted open circuit flux line distribution of proposed PMA- SynRM

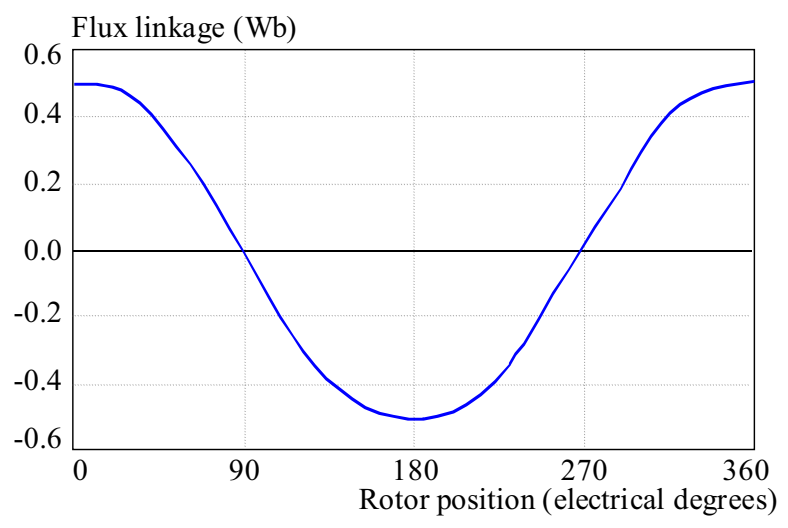

Fig. 7. FE-predicted open circuit flux linkage of proposed PMASynRM

effect of flux barriers and ferromagnetic materials ratio on inductance variation, the outer and inner diameters of rotor keep constant. Predicted inductance variation was shown in Fig. 5. It can be seen that $d$-axis inductance decrease. And the desirable inductance difference and re- luctance torque contribution will increase. However, the flux barriers length cannot exceed a limitation because of $q$-axis flux saturation effect.

\section{PROPOSED PMA-SYNRM}

Main parameters and key dimensions of proposed PM-assisted synchronous reluctance machines have been shown in Table 1. The electromagnetic performance will be evaluated by finite element method in this section, including open circuit flux linkage, back-EMF, cogging torque and electromagnetic torque capability. Figure 6 shows 2D FE-predicted open circuit flux line distribution due to ferrite permanent magnet excitation only. The four poles symmetric flux distribution has been shown in this figure. Figures 7 and 8 show open circuit phase flux linkage, phase back-EMF and associated spectra analysis, respectively. It can be seen that back-EMF waveform consists of third and fifth harmonics component. The harmonics components can be eliminated effectively by winding arrangement optimization.

Table 1. Machines parameters and key dimensions

\begin{tabular}{ll}
\hline Parameter & Value \\
\hline Rated power & $50 \mathrm{~kW}$ \\
Rated speed & $3000 \mathrm{rpm}$ \\
Number of phases & 3 \\
Number of poles & 4 \\
Number of slots & 24 \\
Stator outer diameter & $270 \mathrm{~mm}$ \\
Stator inner diameter & $165 \mathrm{~mm}$ \\
Rotor outer diameter & $163.5 \mathrm{~mm}$ \\
Rotor inner diameter & $86 \mathrm{~mm}$ \\
Axial length & $125 \mathrm{~mm}$ \\
Air-gap length & $0.75 \mathrm{~mm}$ \\
Thickness of magnet & $5 \mathrm{~mm}$ \\
Width of magnet & $50 \mathrm{~mm}$ \\
\hline
\end{tabular}

Figure 9 shows the FE-predicted cogging torque. Cogging torque results from the interaction between permanent magnet and stator slot. It has no contributions for average electromagnetic torque and will increase vibration, noise, and torque ripple, particularly in low speed
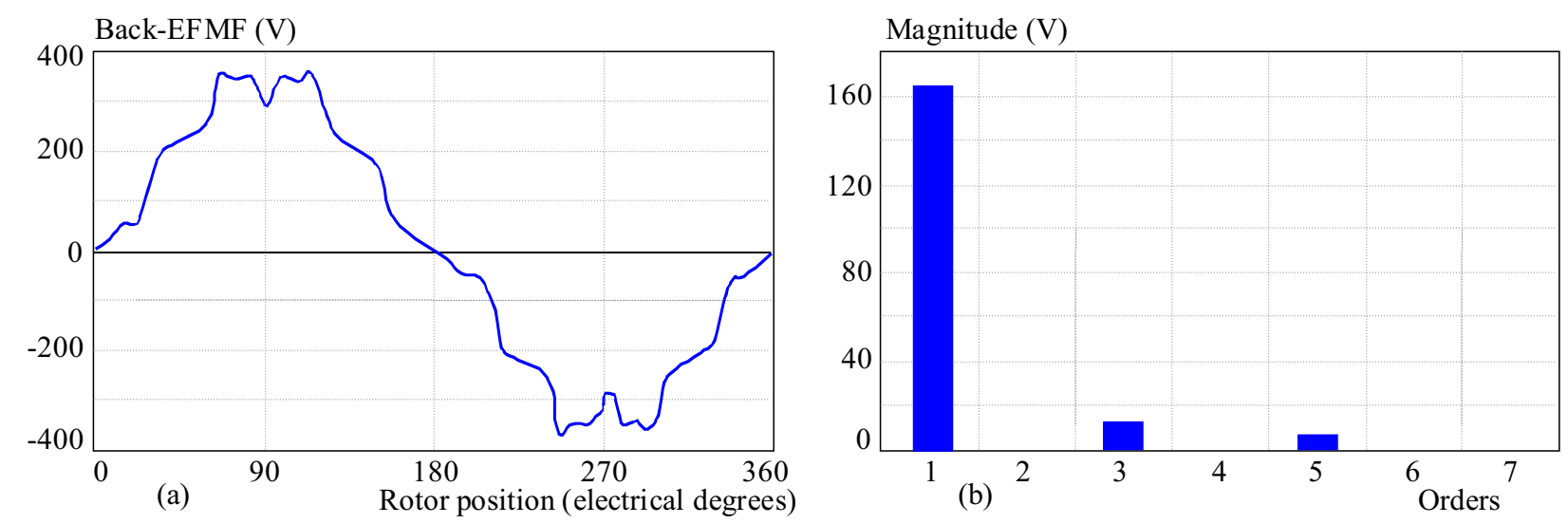

Fig. 8. FE-predicted open circuit flux line distribution of proposed PMA- SynRM, (a) — phase back-EMF waveform, (b) — spectra 


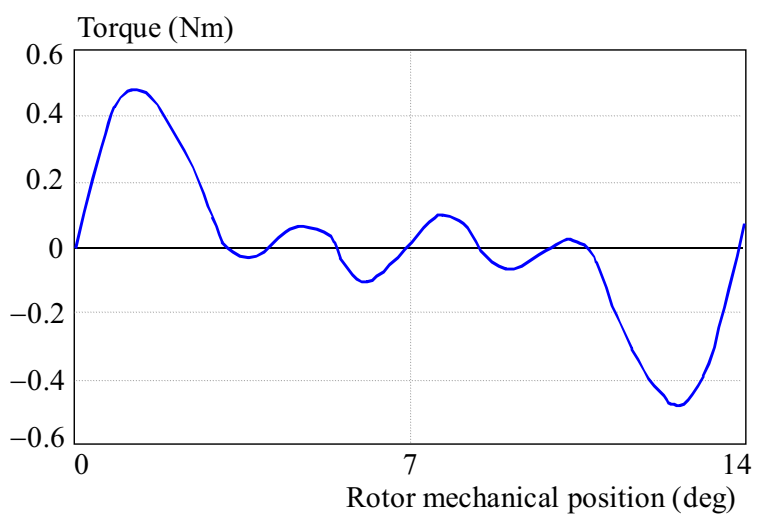

Fig. 9. FE-predicted cogging torque of proposed PMA-SynRM

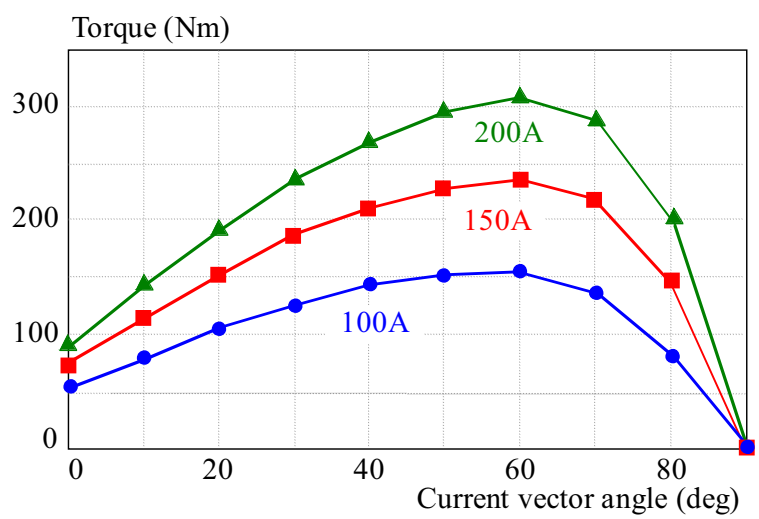

Fig. 11. FE-predicted average electromagnetic torque as a function of current vector angle

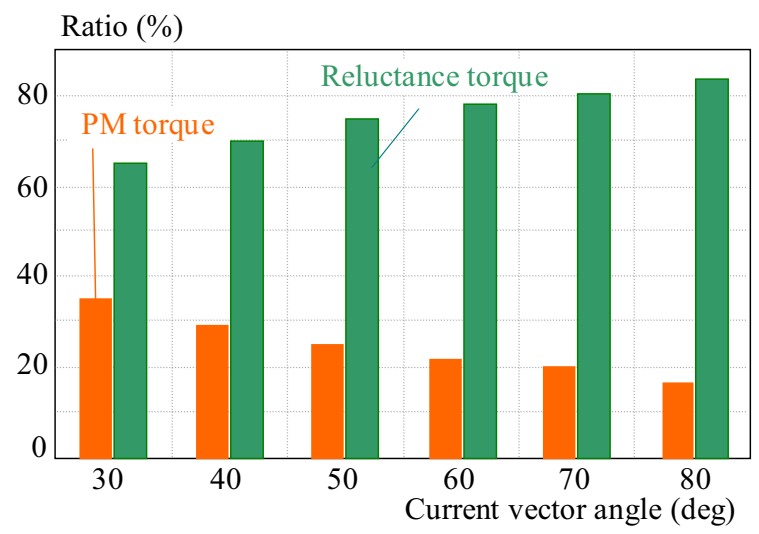

Fig. 13. Permanenr magnet torque and reluctance torque ratio of proposed PMA-SynRM

region. Therefore, some methods, such as skewed slot or magnet, are used to reduce cogging torque in permanent magnet machines [11-14]. Fortunately, the cogging torque of ferrite PM-assisted synchronous reluctance machine is inherent low due to relatively lower airgap flux density, compared to conventional rare earth interior permanent magnet synchronous machines.

Figure 10 shows electromagnetic torque as a function with $q$-axis current. Figure 11 shows electromagnetic torque as function with current vector angle. The impor-

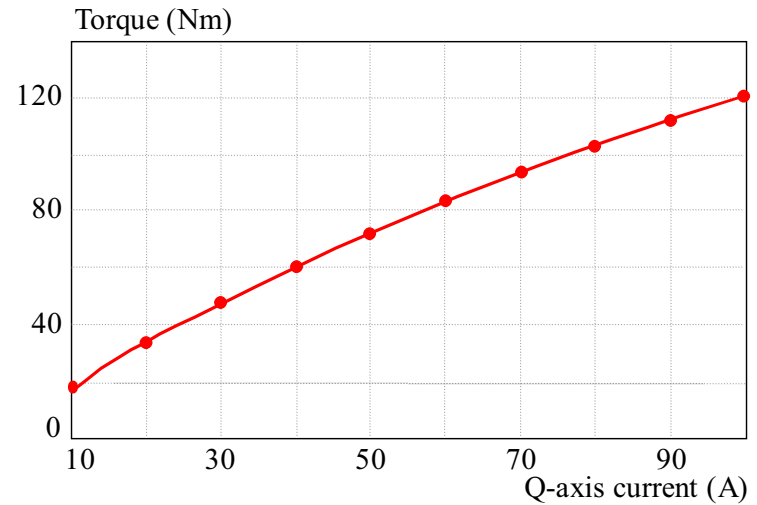

Fig. 10. FE-predicted torque as a function with $q$-axis current

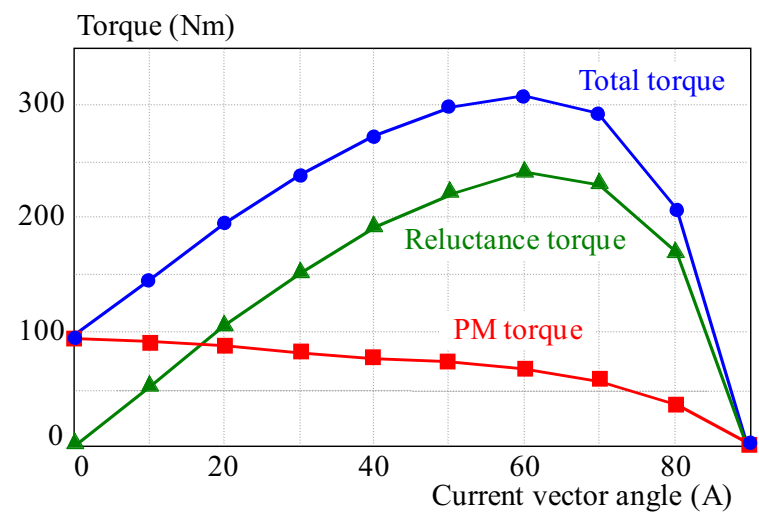

Fig. 12. Permanenr magnet torque and reluctance torque seperation of proposed PMA-SynRM

tant design goal of PM-assisted synchronous reluctance machine is to increase reluctance torque and reduce the use of permanent magnet. The reluctance torque can be enhanced by increase the inductance difference of $d$-axis and $q$-axis magnetic path. Another issue is torque ripple. It can be reduced by rotor flux barriers optimization.

Figure 12 shows the separation of permanent magnet torque and reluctance torque components. It can be seen that the reluctance torque was dominant in total average electromagnetic torque, which differs from conventional rare- earth permanent magnet excited synchronous machines. The torque capability can be enhanced by additional inserted ferrite magnets in rotor lamination, and the power factor willbe improved as well. From Fig. 13, which shows the ratio of reluctance torque and permanent magnet torque component in total average torque, the reluctance torque ratio can reach $35 \%$ to $25 \%$ when current vector angel changed from 30 to 80 degrees. Therefore, the design criteria of PM-assisted synchronous reluctance machines are to maximize the saliency ratio and associated reluctance by optimized design.

\section{CONCLUSION}

Design and rotor geometry analysis of permanent magnet- assisted synchronous reluctance machines us- 
ing low cost ferrite magnets for electric vehicles propulsion has been presented in this paper. The finite element method has been used to calculate inductance with different variation of rotor geometric parameters. The electromagnetic performance of proposed permanent magnet-assisted synchronous reluctance machines, including open-circuit flux linkage, back-EMF, cogging torque, electromagnetic torque capability, have been evaluated as well. From the calculated results presented in this paper, the torque density and other electromagnetic performance can be improved by effective rotor design optimization. The further research results and experimental verification will be presented in the future papers.

\section{REFERENCES}

[1] CHAU, K. T.—ZHANG, D.-JIANG, J. Z.-LIU, C.—ZHANG Y. : Design of a Magnetic-Geared Outer Rotor Permanent Magnet Brushless Motor for Electric Vehicles, IEEE Trans. Magn. 43 No. 6, (June 2007), 2504-2506.

[2] HUA, W.-CHENG, M.-ZHANG, G. : A Novel Hybrid Excitation Flux Switching Motor for Hybrid Vehicles, IEEE Trans. Magn., 45 No. 10 (Oct 2009), 4728-4731.

[3] ZHU, Z. Q.-HOWE, D.: Electrical Machines and Drives for Electric, Hybrid, Fuel Cell Vehicles, Proc. of IEEE 95 No. 4 (Apr 2007), 746-765.

[4] JAHNS, T. M.-KLIMAN, G. B.-EEUMANN, T. W. : Interior Permanent Magnet Synchronous Motors for Adjustable-Speed Drive, IEEE Trans. Ind Appl, 22 No. 4 (July/Aug 1986), 738-747.

[5] MAtSuO, T.-LIPO, T. A.: Rotor Optimization of Synchronous Reluctance Machine, IEEE Trans. Energy Conversion 9 No. 9, 271-350 June 1994.

[6] STAton, D. A.-MILleR, T. J. E.-WOOD, S. E.: Maximising the Saliency Ratio of Synchronous Reluctance Motor, Proc. of IEE 140 No. 4 (July 1993), 249-259.

[7] MORIMOTO, S.—SANADA, M.—TAKEDA, Y.: Performance of PM-Assisted Synchronous Reluctance Motor for High Effi- ciency and Wide Constant Power Operation, IEEE Trans. Ind. Appl. 37 No. 5 (Sep/Oct 2001), 1234-1240.

[8] OOI, S.-MORIMOTO, S.-SANADA, M.—INOUE, Y.: IEEE Trans. Ind. Appl..

[9] BARCARO, M.-BIANCHI, N.-MAGNuSsen, F.: Permanent Magnet Optimization in Permanent Magnet-Assisted Synchronous Reluctance Motor for a Wide Constant Power Speed Range, IEEE Trans. Ind. Electronics 59 No. 6 (June 2012), 2495-2502.

10] NIAZI, P.-TOLIYAT, H. A.-CHEONG, D. H.-KIM, J. C.: A Low Cost Permanent Magnet-Assisted Synchronous Reluctance Motor Drive, IEEE Trans. Ind. Appl. 43 No. 2 (Mar/Apr 2007), 542-550.

[11] LI, T.-SLEMON, G. : Reduction of Cogging Torque in Permanent Magnet Motors, IEEE Trans. Magn. 24 No. 6 (Nov 1988), 2901-2903.

[12] ZHU, Z. Q.-HOWE, D. : Analytical Prediction of the Cogging Torque in Radial-Field Permanent Magnet Brushless Motors, IEEE Trans. Magn. 28 No. 2 (Mar 1992), 1371-1374.

[13] ZHU, Z. Q.-RUANGSINCHAIWANICH, S.-SCHOFIELD, N.-HOWE, D.: Reduction of Cogging Torque in Interior Magnet Brushless Machines, IEEE Trans. Magn. 39 No. 5 (Sep 2003), 3248-3240.

[14] BIANCHI, N.-BOLOGNANI, S.: Design Techniques for Reducing Cogging Torque in Surface-Mounted PM Motors, IEEE Trans. Ind. Appl. 38 No. 5 (Sep/Oct 2002), 1259-1265.

Received 24 July 2015

Zhiwei Zhang received the MS degree in electrical engineering from Hubei University of Technology, Wuhan, Hubei, China, in 2007. He is currently working toward the $\mathrm{PhD}$ degree in Huazhong University of Science and Technology, Wuhan, Hubei, China. His research interests include design, analysis and control of novel electric machines for variable-speed drive and power generation system.

Libing Zhou Zhou received the BS, MS and $\mathrm{PhD}$ degrees in electrical engineering from Huazhong University of Science and Technology, Wuhan, Hubei, China, in 1982, 1985, 1993, respectively. His research interests include theory, application and control of electric machines. 